\title{
Hidrologi Bawah Permukaan Tanah: Studi kasus di Lokasi Pra TPA Kawasan Ilo-Ilo Kecamatan Wori Kabupaten Minahasa Utara
}

\author{
Thevita Refiani Violaa*, As'aria, Seni Herlina Juita Tongkukuta, Zetly \\ Estefanus Tamodb, Deny Ramon Tatuwoc, Lynda Hartatyc, Eva Mariayani \\ Rita Mukuanc, Delfy Boobu Abjulc, Christin Malinggas ${ }^{c}$ \\ aJurusan Fisika, FMIPA, Unsrat, Manado, Indonesia \\ bJurusan IImu Tanah, Fakulktas Pertanian, Unsrat, Manado, Indonesia \\ cBadan Penelitian dan Pengembangan Daerah Provinsi Sulawesi Utara
}

\begin{tabular}{l} 
K A T A K U C I \\
\hline $\begin{array}{l}\text { Hidrologi } \\
\text { Wenner alpha }\end{array}$
\end{tabular}

TERSEDIA ONLINE

01 Februari 2020

KE Y W OR D S

Hydrology

Wenner alpha

\begin{abstract}
A B S T R A K
Sistem hidrologi suatu daerah dipengaruhi oleh bentuk topografi permukaan yang
merupakan daerah tangkapan air hujan. Air hujan yang mengalami infiltrasi ke
dalam tanah menjadi aliran air tanah yang mempunyai pola hidrologi tertentu.
Pemetaan hidrologi air tanah bawah permukaan telah dilakukan di Kawasan llo-llo
desa Wori menggunakan metode geolistrik resistivitas konfigurasi wenner Alpha.
Pengukuran dilakukan pada 4 lintasan dengan spasi elektroda $10 \mathrm{~m}$, 48 elektroda
dan panjang setiap lintasan $480 \mathrm{~m}$. Daerah penelitian terbagi menjadi 2 pola
sistem hidrologi yang terpisah yaitu hasil penelitian menunjukkan bahwa lintasan 3
merupakan area yang mempunyai akuifer paling besar dan permukaannya
merupakan daerah tangkapan air. Air tanah cenderung mengalir ke arah lintasan 3 ,
karena kondisi akuifer yang lebih dalam (> 60 m) pada kedua sistem hidrologi.
A B S T R A C T
The hydrological system of an area is affected by the shape of the surface
topography which is a rainwater catchment area. Rainwater infiltrated into the
soil becomes a groundwater flow that has a certain hydrological pattern. The
mapping of subsurface hydrological groundwater in the llo-llo area of Wori
village using the Wenner Alpha configuration of resistivity geoelecrical
methods has been done. Measurements was made on 4 path with $10 \mathrm{~m}$
electrode spacing, 48 electrodes and length of each path is 480 m. The study
area is divided into 2 separate hydrological system patterns. The result show
us that path 3 is the area that has the largest aquifer and its surface is a
water catchment area. Groundwater tends to flow toward path 3 , due to
deeper aquifer conditions (> 60 m) in both hydrological systems.
A B S T R A K dalam tanah menjadi aliran air tanah yang mempunyai pola hidrologi tertentu. Pemetaan hidrologi air tanah bawah permukaan telah dilakukan di Kawasan Ilo-llo sistem hidrologi yang terpisah yaitu hasil penelitian menunjukkan bahwa lintasan 3 merupakan area yang mempunyai akuifer paling besar dan permukaannya merupakan daerah tangkapan air. Air tanah cenderung mengalir ke arah lintasan 3,
\end{abstract}

\section{Pendahuluan}

Air tanah merupakan air yang terdapat di bawah permukaan tanah, air mengisi pori-pori tanah dan sebagian mengalami migrasi dan yang lain tersimpan dalam akuifer air tanah. Air tanah merupakan salah satu step yang penting bagi manusia. Siklus hidrologi Air hujan yang meresap ke dalam tanah menjadi bagian dari air tanah, perlahan-lahan mengalir ke laut, atau mengalir langsung ke dalam tanah atau diperlukaan dan bergabung dengan aliran sungai. Banyaknya air yang meresap ke tanah bergantung pada ruang dan waktu, selain itu juga dipengaruhi kecuraman lereng, kondisi material permukaan tanah dan jenis serta banyaknya vegetasi dan curah hujan (Febriana dkk, 2017, Gijoh, 2017).

Keberadaan air tanah memerlukan pemeliharaan berkelanjutan. Konservasi air tanah dapat dilakukan dengan menjaga lingkungan dimana air tanah tersebut berada. Pada dasarnya konservasi air tanah tidak hanya ditujukan untuk meningkatkan volume air tanah, tetapi juga meningkatkan konservasi air permukaan. Efisiensi penggunaannya sekaligus mengurangi run off air permukaan yang diharapkan dapat meresap ke 
tanah dan mengisi akuifer menjadi air tanah (Riastika, 2011, Suharyono, 2011).

Air tanah penting bagi manusia dilihat dari segi kuantitas dan kualitasnya, secara kuantitas mencukupi dan secara kualitas tidak tercemar oleh polutan sehingga aman untuk dimanfaatkan. Pencemaran adalah masuk atau dimasukkannya makhluk hidup, zat, energi atau komponen lain ke dalam air. Pencemaran juga bisa berarti berubahnya tatanan (komposisi) air oleh kegiatan manusia dan proses alam, sehingga kualitas menjadi kurang atau tidak dapat berfungsi lagi sesuai dengan peruntukkannya. Dari definisi tersebut tersirat bahwa pencemaran air dapat terjadi secara sengaja maupun tidak sengaja dari kegiatan manusia (Herlambang, 2006).

Polusi air tanah dapat menimbulkan permasalahan yang serius jika tidak diperhatikan. Hal ini disebabkan karena air tanah adalah sumber air yang dimanfaatkan oleh sebagian besar penduduk untuk memenuhi kebutuhan air bersih dan air minum (Herlambang, 2006, Sudarmadji, 2007). Perubahan kondisi kualitas air pada aliran sungai merupakan dampak dari buangan dari penggunaan lahan yang ada (Tafangenyasha dan Dzinomwa, 2005). Perubahan pola pemanfaatan lahan menjadi lahan pertanian, pemukiman dan TPA serta meningkatnya aktivitas industri akan memberikan dampak terhadap kondisi hidrologis dalam suatu daerah aliran sungai (Agustiningsih dkk, 2012, Puluiyo, 2018).

Pencemaran air tanah akan mengikuti pola hidrologi di bawah permukaan tanah, lapisan tanah yang heterogen sifat fisiknya menentukan arah aliran penyebaran polutan. Porositas tanah mempengaruhi pola aliran air tanah, air yang berasosiasi dengan lapisan tanah berpori dapat dikarakteristikkan dengan resistivitas batuan. Kondisi hidrologi bawah permukaan dapat diketahui dengan melihat peta resistivitas lapisan tanah yang diperoleh dari pemetaan menggunakan metode geolistrik.

Limbah cair atau lindi yang merupakan hasil degradasi sampah terutama pada lokasi tempat pengelolaan akhir (TPA) dapat meresap ke dalam tanah hingga mencemari sumber air tanah. Penelitian mengenail infiltrasi air tanah pernah dilaksanakan di sekitar TPA Sumompo, Manado dengan menggunakan konfigurasi WennerSchlumberger. Hasil analisis menunjukan adanya zona-zona resistivitas rendah yang diperkirakan sebagai daerah porous tersaturasi fluida. Pada lintasan 1, zona tersebut diinterpretasikan sebagai daerah rembesan dan akumulasi lindi, sementara pada lintasan-lintasan yang lain diperkirakan sebagai zona air tanah yang berpotensi tercemar lindi (Datunsolang dkk, 2015).

Penelitian ini dilakukan di lokasi pembangunan Tempat Pengolahan Akhir (TPA) regional di Kawasan Ilo-Ilo Desa Wori. TPA tersebut akan mempunyai dampak terhadap hidrologi, perubahan bentuk permukaan kawasan dan peruntukannya memerlukan pemantauan untuk menjaga keberlangsungan dan kelestarian lingkungan. Pemantauan secara kontinyu berguna untuk meminimalisir dan meniadakan efek negatif dari pencemaran yang terjadi.

\section{Material dan Metode}

Penelitian menggunakan metode geolistrik resistivitas konfigurasi Wenner Alpha. Akuisisi data menggunakan georesistivitymeter MAE X612-EM dan data koordinat diukur menggunakan GPS Garmin etrex. Pengukuran dilakukan pada 4 lintasan, panjang setiap lintasan adalah 480 m, 48 elektroda, spasi antar elektroda $10 \mathrm{~m}$. Data diolah menggunakan perangkat lunak Notepad dan diinversi dengan Res2Dinv. Peta lokasi pengukuran menggunakan peta dari google earth pro(Gambar $1)$.

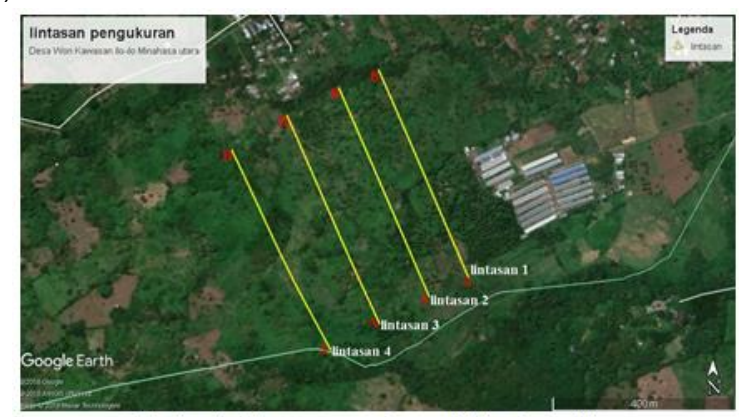

Gambar 1. Lintasan pengukuran di lokasi penelitian

\section{Hasil dan Pembahasan}

Pada daerah penelitian terdapat beberapa vegetasi antara lain: rumput, ilalang, tanaman kebun berupa pisang, kelapa, bambu dan beberapa pohon hutan dan semak belukar. Dijumpai banyak singkapan batuan besar (bolder), tersebar di lokasi yang cenderung berbukit. Pengambilan data dilakukan dengan jarak antara Lintasan 1 dan Lintasan 2 adalah 90 m, Lintasan 2 dan Lintasan 3 adalah $120 \mathrm{~m}$, Lintasan 3 dan Lintasan 4 adalah $120 \mathrm{~m}$. Data hasil pengukuran diolah menggunakan software Res2Dinv, yang menggambarkan kondisi lapisan bawah permukaan yang diwakili oleh tampang lintang variasi resistivitas. Resistivitas atau tahanan jenis suatu bahan adalah besaran atau parameter yang menunjukkan tingkat hambatan terhadap arus listrik.

Pada gambar cross section, sumbu horizontal menyatakan jarak lintasan (dalam meter $(\mathrm{m})$ ) yang terdiri atas dua bagian A dan B, yang juga mewakili posisi elektroda. Elektroda 1 - 24 (bagian A) dan elektroda 25 - 48 (bagian B). Sumbu vertikal mewakili kedalaman dari permukaan tanah (dalam satuan meter $(m))$. Tampang lintang resistivitas lintasan 1 ditunjukkan pada Gambar 2.

Gambar 2 menunjukkan bahwa terdapat dugaan akuifer pada meter ke 110 - 160 dengan kedalaman $\geq 10 \mathrm{~m}$. Akuifer air tanah diidentifikasi dengan nilai resistivitas $\leq 24 \Omega \mathrm{m}$. Area resapan beresistivitas 36 - $40 \Omega \mathrm{m}$ (warna kuning) terletak pada meter ke 160 - 180 . 


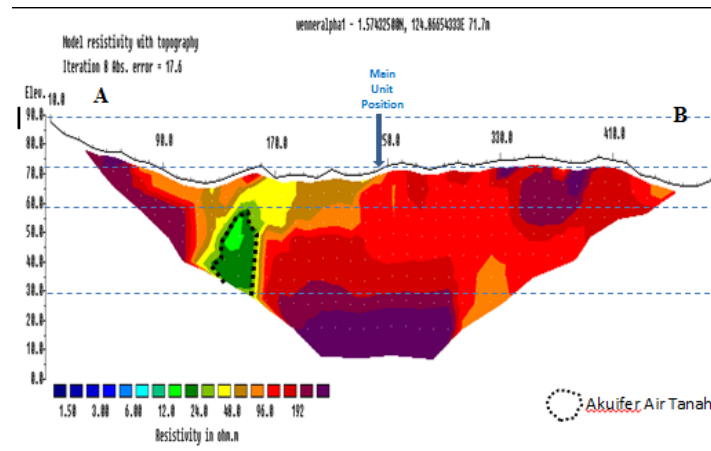

Gambar 2. Cross section bawah permukaan tanah Lintasan 1

Kondisi lapisan bawah permukaan Lintasan 2 tampak pada Gambar 3, terdapat dua akuifer air tanah ( $\rho \leq 24 \Omega m$ ) berkapasitas besar yaitu pada meter ke 150 - 190 dengan kedalaman 35 - 65 m dan pada meter ke 175 - 210 dengan kedalaman 10 - $40 \mathrm{~m}$. Selain itu juga tersebar spot-spot akuifer kecil sebanyak 7 buah di sepanjang lintasan.

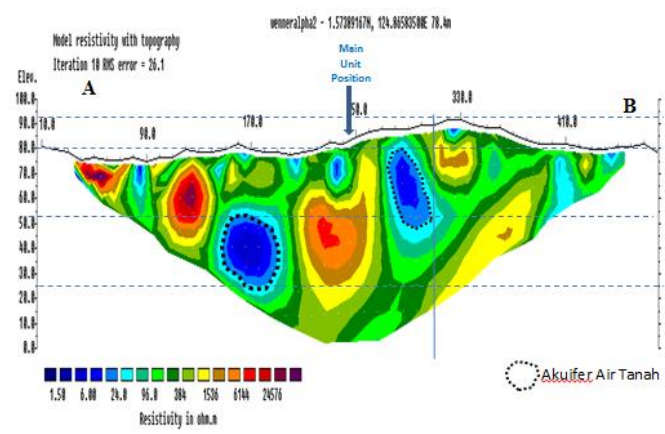

Gambar 3. Cross section bawah permukaan tanah Lintasan 2

Pada Lintasan 3 terdapat dua sistem akuifer air tanah, yaitu 1) pada meter ke 35 - 240 dengan kedalaman sampai $60 \mathrm{~m}$, antara akuifer besar dan kecil saling terhubung dan menerus satu dengan yang lain dan 2) pada meter ke 260 - 340 dengan kedalaman sampai $60 \mathrm{~m}$, antara akuifer satu dengan yang lain saling berhubungan dan menerus (Gambar 4). Diduga akuifer mempunyai kedalaman yang lebih besar (> $60 \mathrm{~m}$ ).

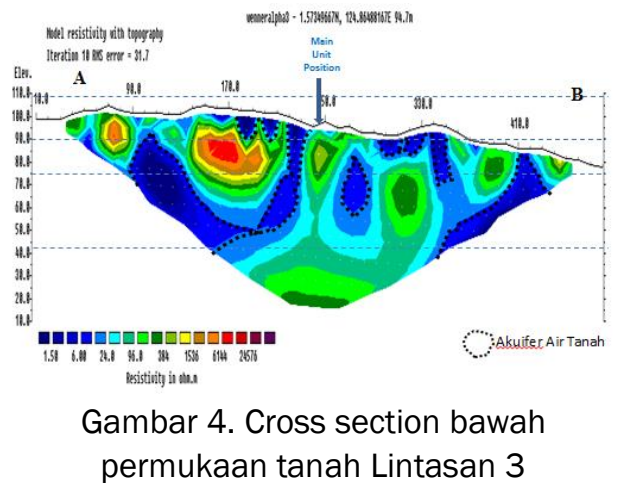

Pada Lintasan 4 terlihat hanya terdapat satu dugaan akuifer air tanah pada meter ke 280 - 310 dengan kedalaman $\geq 63 \mathrm{~m}$, terdapt pula spot akuifer air tanah dangkal dekat permukaan dengan kapasitas kecil pada meter ke 240-250 dan pada meter ke 320 - 330(Gambar 5).

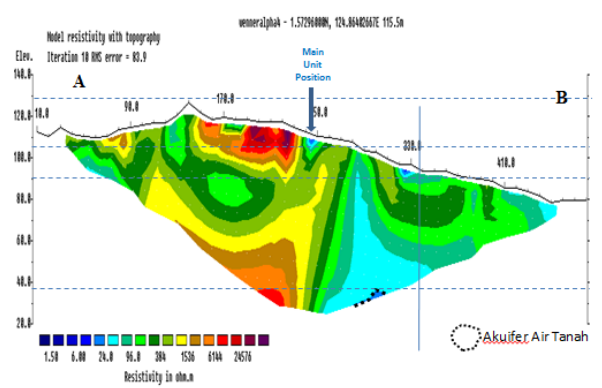

Gambar 5. Cross section bawah permukaan tanah Lintasan 4

Gambar 6 menunjukkan bahwa Lintasan 3 mempunyai akuifer air tanah terbesar diikuti Lintasan 2, Lintasan 4 dan Lintasan 1. Lokasi penelitian terdiri atas 2 sistem pola hidrologi bawah permukaan tanah yaitu bagian $A$ dan bagian $B$, berdasarkan topografi permukaan tanah bahwa area bagian A dan bagian B mempunyai daerah resapan atau tangkapan air hujan yang berbeda. Pada kedua area di bagian A dan bagian B terdapat kecenderungan aliran fluida menuju ke Lintasan 3. Hal ini diindikasikan dengan posisi akuifer yang lebih dalam pada kedua bagian di Lintasan 3 .

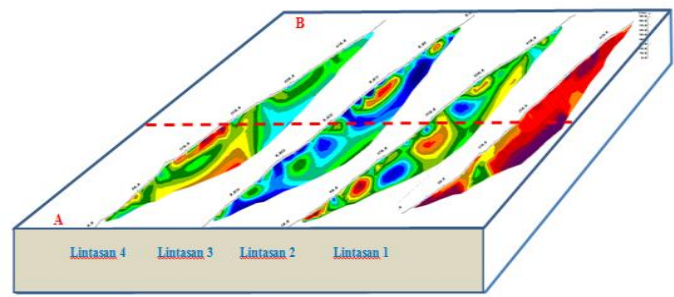

Gambar 6. Empat Lintasan pengukuran

\section{Kesimpulan}

Investigasi menggunakan metode geolistrik konfigurasi Wenner Alpha menunjukkan bahwa pola hidrologi Kawasn Ilo-llo di lokasi penelitian terbagi menjadi dua sistem yang terpisah. Lintasan 3 merupakan area yang mempunyai akuifer paling besar dan permukaannya merupakan daerah tangkapan air. Air tanah cenderung mengalir ke arah lintasan 3, karena kondisi akuifer yang lebih dalam (> $60 \mathrm{~m}$ ) pada kedua sistem hidrologi.

\section{Daftar Pustaka}

Agustiningsih, D., Sasongko, S.B., Sudarno.2012. Analisis kualitas air dan strategi pengendalian pencemaran air sungai blukar kabupaten Kendal. Jurnal Presipitasi. 9(2):64-71

Datunsolang, F., Gerald T., As'ari. 2015. Identifikasi Rembesan Limbah Cair dengan Menggunakan Metode Geolistrik Konfigurasi Wenner Schlumberger Studi Kasus TPA Sumompo, Manado. Jurnal IImiah Sains. 15(2): 167-172. 
Febriana, N.K.R., Muniarto, E., Tryono, Y.2017. Identifikasi Sebaran Aliran Air Bawah Tanah(groundwater) Dengan Metode Vertical Electrical Sounding (VES) Konfigurasi Schlumberger Di Wilayah Cepu, Blora Jawa Tengah. Jurnal Sains dan Seni Its. 6(2): 110.

Gijoh, O. T., As'ari., Pasau, G. 2017. Identifikasi Akuifer Air Tanah Di Masjid Kampus Universitas Sam Ratulangi dan Sekitarnya dengan Menggunakan Metode Geolistrik Tahanan Jenis Konfigurasi Dipol- dipol. Jurnal MIPA UNSRAT Online Manado. 6(1): 1720

Herlambang, H. 2006. Pencemaran Air dan Strategi Penanggulangannya. Jurnal Air Indonesia (JAI). 2(1): 16-29.

Puluiyo, J., As'ari., Tongkukut, S. H. J. 2018. Perbandingan Konfigurasi Wenner Alfa, WennerSchlumberger, Dipol-dipol Dan Pol- dipol Dalam Metode Geolistrik Tahanan Jenis Untuk Mendeteksi Keberadaan Air Tanah. Jurnal MIPA UNSRAT Online. 7(1) 29-33.

Riastika, M. 2011. Penggelolaan Air Tanah Berbasis Konservasi Recharge Area Boyolali (Studi Kasus Recharge Area Cepogo, Boyolali, Jawa Tengah). Jurnal ilmu lingkungan $\quad$ (JIL). 9(2): 86-97.

Sudarmadji. 2007. Perubahan Kualitas Airtanah Di Sekitar Sumber Pencemar Akibat Bencana Gempa Bumi. Forum Geografi, 20(2):99-119.

Suharyono, Y.A. 2011. Perencanaan Embung Kalen Desa Hargosari Kecamatan Tanjung Sari Kabupaten Gunung Kidul Yogyakarta. [skripsi]. FT UAJ, Jakarta.

Tafangenyasha, C and T. Dzinomwa. 2005. Land use impacts on river water quality in lowveld sand river systems in south- east Zimbabwe. Land use and water resources research 5 : 3.13.10 